\title{
Agrarinių teritorijų naudojimo problemos ir jų sprendimas Lietuvoje
}

Pranas Aleknavičius,

Audrius Aleknavičius,

Daiva Juknelienè

Aleksandro Stulginskio universitetas,

Studentu g. 11,

LT-53361 Akademija, Kauno r.

El.paštas: pranas.aleknavicius@gmail.com; audrius.aleknavicius@asu.lt; daiva.jukneliene@asu.lt
Straipsnyje pateikiama Lietuvos Respublikos žemès ūkio paskirties žemės būklès apžvalga ir pasiūlymai agrarinių teritorijų tvarkymo reguliavimui. Analizuojamos priežastys, sąlygojančios žemès naudojimo intensyvumo lygị. Pateikiami pasiūlymai žemès ūkio ir kaimo plètrai, galintys užtikrinti efektyvesni žemès ūkio paskirties žemès naudojimą. Siūlymai pagrindžiami strateginių dokumentų ir ịstatymų nuostatomis žemès ūkio naudmenų, kaip išskirtinès reikšmès gamtos ištekliaus, išsaugojimui. Racionalaus žemès naudojimo klausimai Lietuvoje gali būti tinkamai sprendžiami patobulinus teisès aktus, rengiant mokslinėmis rekomendacijomis pagrisstus teritoriju planavimo dokumentus, apleistas žemes grąžinus ūkinei veiklai. Tai leistų stabilizuoti žemès ūkio naudmenų ploto mažèjimą.

Raktažodžiai: žemès ūkio paskirties žemė, žemès ūkio naudmenos, žemès naudojimo intensyvumas, apleistos žemès, žemès našumas

\section{IVADAS}

Lietuvos Respublikos Konstitucinio Teismo išaiškinimu, žemès, kaip išskirtinio gamtos ištekliaus, racionalus naudojimas yra viešasis interesas (Lietuvos..., 2006). Tai ịpareigoja valstybę imtis priemonių teisiškai reguliuoti privačios ir valstybinès žemès naudojimą. Lietuvos Respublikos ilgalaikès plètros strategijoje (Lietuvos..., 2002b) numatyta, kad kaimo ir žemès ūkio plètros srityje valstybès politika užtikrins ekonomikos, ekologijos ir socialiniu požiūriu tolygią plètotę; bus sukurtos teisinès ir ekonominès racionalaus gamtos išteklių naudojimo prielaidos. Žemès ūkio šakos, kuri naudoja daugiau kaip $60 \%$ šalies teritorijos, plètros perspektyvinès gairès - i rinką orientuotas, konkurencingas žemès ūkis; valstybès parama žemès ūkiui; aplinkos apsauga, tausojamasis, dirvožemị gerinantis, biologinę ịvairovę ir kraštovaizdi puoselèjantis ūkininkavimas; tolygi kaimo ekonominè ir socialinè plètra, atitinkanti regionų ypatumus.

Administruojant žemès naudojimą, būtina sugebèti tinkamai derinti privačius ir viešuosius interesus, o numatomas priemones planuoti ịvertinant specifines žemès, kaip ūkinių struktūru komponento bei gamtinès aplinkos dalies, savybes. Žemès ūkio bei miškų ūkio veiklai naudojama žemè - tai ypatingas gamtos išteklius, pasižymintis derlingojo dirvožemio sluoksniu. Joje akumuliuotas daugelio žmonijos kartų darbas ir valstybės ar kaimo bendruomenių lěšos. Per šimtmečius naudojant žemę pasèliams, joje iškirsti krūmai ir sureguliuotas drégmès režimas, išrinkti akmenys, dirvožemis organinių trąšų dekka praturtintas humusu. Socialistiniu laikotarpiu atliktiems žemès ūkio paskirties žemès kultūrinimo darbams priskirtina užmirkusių plotų nusausinimas, kelių, reikalingų privažiavimui ị laukų masyvus, tiesimas, mechanizuotam dirbimui pritaikytų lauku suformavimas, kultūrinių pievų ir ganyklų ịrengimas žolinių pašarų auginimui numatytose vietose. Ši žemé, tinkamai ją naudojant, nepraranda savo vertès. Žemès naudojimo ilgalaikis tikslas - gerinti žemès ūkines savybes, tausoti žemès ūkio naudmenas, miškus ir kitus gamtos išteklius. Šiam tikslui pasiekti būtina rengti teritorijų planavimo 
dokumentus, suderinančius gamtines bei ūkines sistemas, ir šių dokumentų pagrindu teisiškai bei ekonomiškai reguliuoti gamybos augimą.

Atsižvelgiant ị maisto produktų poreikị didèjančiam pasaulio gyventoju skaičiui, žemès ūkio naudmenų išsaugojimas bei efektyvus naudojimas yra nacionalinès svarbos uždavinys. Tai pažymima ir tarptautiniuose strateginiuose dokumentuose. Jungtinių Tautų aplinkos ir plètros konferencijoje Rio de Žaneire (1992 m. birželio 3-14 d.) priimtame dokumente „Darbotvarkè 21: Subalansuotos plètros veiksmų programa" pabrèžtas darnaus, subalansuoto žemés išteklių planavimo ir naudojimo poreikis. Dokumente nurodoma, kad:

1) siekiant racionaliai planuoti žemès išteklių naudojimą, būtina patikima informacinè sistema ir žemès apskaita;

2) žemès naudojimo paskirtis turi būti nustatoma taip, kad jos naudojimas duotų didžiausią naudą, tačiau turi būti užtikrintas interesų balansas;

3) ypač svarbus teritorijų planavimo vaidmuo; būtina rengti žemètvarkos planus, numatančius žemès išteklių racionalų naudojimą;

4) būtina išsaugoti ir pagerinti žemès ūkiui tinkamas žemes, užtikrinti dirvožemio derlingưju savybių apsaugą: „Tam tikro lygio vyriausybinès organizacijos <...> turi užtikrinti, kad politikos kryptys ir priemonès parems geriausią ímanomą žemès naudojimą ir žemès išteklių subalansuotą valdymą. Ypač daug dèmesio turi būti kreipiama ì žemès ūkio paskirties naudmenas. Tam būtina: išnagrinèti priežiūros struktūrą - įstatymus, taisykles bei vykdymo procedūras, siekiant apibrèžti naujoves, reikalingas subalansuotam žemès naudojimui paremti ir žemès ištekliams valdyti, taip pat apriboti našios ariamosios žemès perdavimą kitokiems tikslams" (Darbotvarkè..., 2001).

Europos kaimiškųjų sričių chartijoje, priimtoje Europos Tarybos Parlamentineje Asamblejoje $1995 \mathrm{~m}$. liepos 28 d., nustatyta, jog pagrindinès kaimo vietovių funkcijos - ekonominè (žaliavos maisto produktams ir pramonei išauginimas), socialinė (žmogaus ryšio su natūralia aplinka išsaugojimas) ir ekologine (gamtos išteklių racionalus naudojimas ir apsauga). Pažymima tai, kad būtina išvengti prasidejjusių neigiamų tendencijų - kaimo gyventojų skaičiaus mažèjimo ir tradicinio ùkininkavimo būdo praradimo. Šiame dokumente pateikiamos bendrosios nuostatos Europos šalių kaimiškoms sritims vystyti. Nurodoma, kad re- gioninè (kaimo plètros) ir žemés dirbimo politika turi būti derinama su integruota socialine ir ekonomine politika. Valstybės turètų skatinti kuo racionalesnio dydžio ūkius, kurių funkcionavimas būtų ekonomiškai naudingas. Taip pat būtina garantuoti racionalų ir tolygų gamtos išteklių naudojimą, išsaugoti gyvenamąją aplinką, jos biologinę ìvairovę, saugoti visą vertingą kraštovaizdị, tausoti miškus ir apsodinti nenaudojamas žemdirbystei vietas. Kaimas išliks patrauklia ir saugia gyventi vieta, jeigu jis turès gerą infrastruktūrą, gyvybingą žemdirbystę ir miškininkystę, bus patogus ne žemès ūkio ekonominei veiklai vystyti, turès sveiką ir patogią aplinką (European..., 1996).

Pagrịsdamas valstybinio žemès naudojimo reguliavimo poreiki žemètvarkos priemonèmis ir teisès aktu reikalavimais, Rusijos Federacijos akademikas S. N. Volkovas teigia: „Dauguma mokslininkų ir ekspertų mano, kad valstybini žemès santykių reguliavimą užsienio šalyse reikia vertinti ne kaip valstybès ịsikišimą i žemès ir kito nekilnojamojo turto rinkos procesus, o kaip vidaus socialinès-ekonominès politikos sudedamąją dalį, užtikrinant subalansuotą teritorijos vystymą. Dèl to kartu su įvairiomis finansinio-ekonominio reguliavimo priemonemis taikomas teritorijų vystymo planavimo ir zonavimo mechanizmas ir kiti žemès naudojimo ribojimai. Praktika parodè, kad šalys, kuriose didinamas valstybès poveikis žemès rinkai, pasiekia esminès pažangos vystant žemès naudojimą, nei tos, kurios, įvykdžiusios žemès reformą, sumažino valstybès poveikį žemès santykių reguliavimui. Šalys, pastaruoju metu sustiprinusios valstybini žemès santykių reguliavimą žemètvarkos pagalba, išsaugojo optimalų skirtingų žemès grupių (žemés ūkio, miškų ūkio, saugomų teritorijų, gyvenamųjų teritorijų) balansą" (Volkov, 2005).

Rengiant pasiūlymus tolesniam žemès ūkio ir kaimo plètros planavimui, būtina atsižvelgti ì žemés ūkio naudmenų racionalaus naudojimo reguliavimo galimybes. Šiame straipsnyje aptariamų tyrimų tikslas - ištirti valstybès žemès ūkio paskirties žemès naudojimo raidos tendencijas ir nustatyti pagrindines racionalaus žemès naudojimo kryptis. Tikslui pasiekti keliami uždaviniai:

- išnagrinèti strateginius dokumentus, įstatymus, kitus teisès aktus žemès administravimo klausimais;

- išnagrinèti pagrindinius statistinius rodiklius šalies regionuose, apibūdinančius žemès naudojimą 
ir žemès ūkio sistemos raidos pokyčius nuo 2003 metų;

- pateikti pasiūlymus agrarinių teritorijų naudojimo problemų sprendimui.

\section{TYRIMŲ METODAI IR SĄLYGOS}

Atliekant tyrimus panaudoti matematiniai statistiniai metodai, teisès aktų bei mokslinès literatūros analizè, statistinių duomenų analizè ir abstrahavimas.

Tyrimams panaudoti strateginiai dokumentai, Lietuvos Respublikos ịstatymai ir Vyriausybès nutarimai, Visuotinio žemès ūkio surašymo duomenys, žemès valstybinès apskaitos, žemès ūkio naudmenų ir pasèlių deklaravimo duomenys, kiti statistiniai duomenys apie žemès plotus, gyventoju skaičių bei žemès ūkio gamybos apimtis kaimiškųjų savivaldybių teritorijose.

\section{TYRIMŲ REZULTATAI IR JŲ APTARIMAS}

Esamos tendencijos. Žemès ūkio paskirties žemès naudojimo efektyvumui esminę ịtaką Lietuvoje turẻjo žemès ūkio įmonių turto privatizavimas ir jų reorganizavimas $\mathfrak{i}$ smulkesnius ūkinius vienetus, nuosavybès teisių i̇ žemę atkūrimas, taip pat pakitusios rinkos ekonomikos sąlygos, ribotos galimybès skirti nacionalinio biudžeto lěšas sausinimo sistemų rekonstrukcijai bei kitiems pablogèjusių žemès ūkio naudmenu gerinimo darbams, kryptingai vykdomos ES fondų finansinès paramos priemonès.

Statistinių duomenų analizè rodo, jog per 40 metų laikotarpi (1949-1989) žemès ūkio paskirties žemèje esančių žemès ūkio naudmenų plotas Lietuvoje sumažèjo nuo 4 124,7 tūkst. ha iki 3 373,0 tūkst. ha, arba 741,7 tūkst. ha. 2009 m. naudojamų žemès ūkio naudmenų plotas sudarè tik 2641,0 tūkst. ha, t. y. per 19 metų sumažèjo 732,0 tūkst. ha (A. Aleknavičius, P. Aleknavičius, 2010). Be to, vertinant ši agrarinès reformos laikotarpi, pastebimos ir kitos neigiamos tendencijos: dirvožemio ūkinių savybių blogẻjimas, javų ar kitų prekinių žemés ùkio augalų pasèliams tinkamų ariamosios žemès plotų ekstensyvus panaudojimas. Ūkininkavimo sistemos transformacija ir pakitusios ekonominès sąlygos turëjo ittakos žemès ūkio paskirties žemès naudojimo būklei. J. Jasaitis (2008) nurodo tokias neigiamas agrarinès reformos pasekmes: „Anaiptol ne visi atgavusieji žemę turi galimybę ūkininkauti... Iš kaimo gyvenviečių išvyko jaunesni, labiau kvalifikuoti ir ekonomiškai aktyvesni asmenys. <...> Daugiau kaip pusė kaimo gyventojų nebelaiko karvių ir kiaulių, du trečdaliai neturi jokio inventoriaus žemès ūkio darbams." Analizuodamas žemés ūkio naudmenų plotų pokyčius žemès reformos laikotarpiu, G. Ribokas (2010) konstatuoja, jog „didžiausią ịtaką tiems procesams <...> turejo kolektyvinių ūkių bankrotas ar sunaikinimas, po kurio didelè dalis žemès liko mažiau prižiūrima. $<\ldots>$ Dar prieš 20 metų efektyviai funkcionavusios melioracijos sistemos nebeatlieka savo funkcijų, todèl anksčiau drenuotos žemès pradejjo pelkèti ir apaugo krūmais ar medžiais."

Dèl Lietuvoje įvykdytos žemès reformos restitucinio pobūdžio šiuo metu ūkiai tik apie pusę savo naudojamos žemès ploto turi ìsigiję nuosavybès teise (1 lentelè).

Ūkininkų ūkių registre $2013 \mathrm{~m}$. sausio 1 d. irregistruoti ūkiai pagal naudojamų žemès ūkio naudmenų plotą (įskaitant nuosavą ir išsinuomotą žemę) pasiskirstè taip: 747 ùkiai buvo stambesni kaip 300 ha; 3358 ūkiai naudojo 100-300 ha; 5235 ūkiai - 50-100 ha; 13103 ùkiai - 20-50 ha; 20453 ùkiai - 10-20 ha; 40577 ūkiai - 3-10 ha; 31153 ūkiai - iki 3 ha. Tai rodo, jog apie 1/4 ūkininkų neturi pakankamai žemès, reikalingos prekinei žemès ūkio produkcijai išauginti. Ūkių stambejjimas daugiausiai vyksta žemès ūkio veiklos subjektams perkant valstybinę ir privačią žemę.

Valstybinès žemès ūkio paskirties žemės privatizavimo rodikliai: $2010 \mathrm{~m}$. privačios žemès plotas padidejo 52,8 tūkst. ha (iš to ploto parduodant valstybinę žemę - 36,2 tūkst. ha); $2011 \mathrm{~m}$. - 67,0 $(44,1)$ tūkst. ha; 2012 m. - 87,1 (49,9) tūkst. ha; 2013 m. I pusmetị - 43,6 (30,7) tūkst. ha. Iš 27,4 tūkst. pageidavimų (iki prašymų prièmimo sustabdymo 201108 24) pirkti 442 tūkst. ha laisvos valstybinès žemès per 9 metų laikotarpi patenkinta tik apie pusé: 20130701 dar buvo neparduota 204 tūkst. ha. Be to, dar yra 200 tūkst. ha valstybinès žemès, kurią pirkti gali būti pageidaujama vèliau.

Privačios žemės perleidimų (pardavimų ir dovanojimų) vidutinès apimtys - apie 60-70 tūkst. žemès sklypų (150-170 tūkst. ha) per metus, t. y. apie $5 \%$ kasmet nuo viso privačios žemès ploto. 
1 lentelè. Žemès priklausomybẻ nuosavybès teise (žemės ūkio naudmenų plotas tūkst. ha) $2013 \mathbf{~ m . ~}$

Table 1. Land dependence on ownership rights in 2013 (agricultural land area in thousand ha)

\begin{tabular}{|c|c|c|c|c|c|c|}
\hline \multirow{2}{*}{$\begin{array}{c}\text { Žemès savininkü ir (ar) } \\
\text { naudotojų grupès } \\
\text { Groups of land owners and (or) } \\
\text { users }\end{array}$} & \multicolumn{3}{|c|}{$\begin{array}{l}{ }^{\star} \text { Turi nuosavybès teise ir } \\
{ }^{\star} \text { Have ownership rights and }\end{array}$} & \multicolumn{2}{|c|}{$\begin{array}{l}\text { *Nuomoja žemès ūkio } \\
\text { veiklai iš } \\
{ }^{*} \text { Are leasing for agri- } \\
\text { cultural activity from }\end{array}$} & \multirow{2}{*}{$\begin{array}{c}\text { Iš viso } \\
\text { naudoja } \\
\text { Use } \\
\text { totally }\end{array}$} \\
\hline & $\begin{array}{c}\text { naudoja } \\
\text { patys } \\
\text { use them- } \\
\text { selves }\end{array}$ & $\begin{array}{c}\text { nuomoja } \\
\text { kitiems } \\
\text { lease to } \\
\text { others }\end{array}$ & $\begin{array}{l}\text { nenaudoja } \\
\text { do not use }\end{array}$ & $\begin{array}{l}\text { valstybès } \\
\text { the state }\end{array}$ & $\begin{array}{c}\text { kitụ } \\
\text { savininku } \\
\text { other } \\
\text { owners }\end{array}$ & \\
\hline \multicolumn{7}{|c|}{$\begin{array}{l}\text { Žemès ūkio veiklos subjektai (160 tūkst.) } \\
\text { Subjects of agricultural activity (160 thous.) }\end{array}$} \\
\hline $\begin{array}{l}\text { Fiziniai asmenys } \\
\text { Natural persons }\end{array}$ & 1300 & $\mathrm{x}$ & $\mathrm{x}$ & 280 & 840 & 2420 \\
\hline $\begin{array}{l}\text { Juridiniai asmenys } \\
\text { Legal persons }\end{array}$ & 160 & $\mathrm{x}$ & $\mathrm{x}$ & 45 & 175 & 380 \\
\hline \multicolumn{7}{|c|}{$\begin{array}{l}\text { Kiti žemės savininkai (390 tūkst.) } \\
\text { Other land owners (390 thous.) }\end{array}$} \\
\hline $\begin{array}{l}\text { Fiziniai asmenys } \\
\text { Natural persons }\end{array}$ & $\mathrm{x}$ & 985 & 400 & $\mathrm{x}$ & $\mathrm{x}$ & $\mathrm{x}$ \\
\hline $\begin{array}{l}\text { Juridiniai asmenys } \\
\text { Legal persons }\end{array}$ & $\mathrm{x}$ & 30 & - & $\mathrm{x}$ & $\mathrm{x}$ & $\mathrm{x}$ \\
\hline $\begin{array}{l}\text { Valstybè } \\
\text { The State }\end{array}$ & $\mathrm{x}$ & 325 & 140 & $\mathrm{x}$ & $\mathrm{x}$ & $\mathrm{x}$ \\
\hline $\begin{array}{c}\text { Iš viso } \\
\text { Total } \\
\end{array}$ & 1460 & 1340 & 540 & 325 & 1015 & 2800 \\
\hline
\end{tabular}

Šaltiniai / Sources: Vḷ Registrų centras; Nacionalinė mokèjimo agentūra / Center of Registers, National Payment Agency. Pastaba / Note: ${ }^{\star}$ duomenys pagristi apytiksliais skaičiavimais / data grounded on preliminary calculations.

Didelè dalis šių žemès sklypų atitenka ne juos naudojantiems asmenims. Tai atvejai, kai žemès ūkio paskirties žemès sklypus supirkinëja fiziniai ir juridiniai asmenys, siekiantys pasipelnyti iš žemès perpardavimo ar nuomos.

2013 m. liepos 1 d. Nekilnojamojo turto registre irregistruota 591 tūkst. ha žemès, naudojamos pagal privačios nuomos sutartis, 207 tūkst. ha - pagal panaudos sutartis. Likusio ploto, kurị naudoja ne patys žemès savininkai (apytiksliais skaičiavimais - 200 tūkst. ha), naudojimui gali būti sudarytos trumpalaikès, neregistruotos nuomos ar panaudos sutartys. 93 tūkst. ha įregistruotas plotas naudojamas pagal valstybinès žemès nuomos sutartis, 9 tūkst. ha - pagal panaudos sutartis. Likęs naudojamos valstybinès žemès plotas (apie 220 tūkst. ha) itteisintas valdymo institucijų sprendimais dèl žemès suteikimo naudoti žemès ūkio veiklai.

Svarbiausios ūkininkų problemos, iškylančios nuomojant privačią žemę:
1) nèra galimybių planuoti ūkio plètros perspektyvas, ilgesnị laikotarpi negarantuojamas žemès naudojimo išsaugojimas;

2) žemès savininkai neinvestuoja lèšų privažiavimo keliams ir sausinimo sistemų įrenginiams pagerinti, jų gautos lèšos iš žemès nuomos panaudojamos ne žemès ūkyje. Privačios žemès nuomos mokestis yra iki 10 kartų didesnis nei savininko mokamas valstybei žemės mokestis;

3) žemès kainos ir nuomos mokestis kasmet dideja, todèl augančios žemès pirkimo ir nuomos išlaidos sulètina ūkių ekonominị augimą;

4) valstybès parama žemès gerinimo darbams yra tik minimali, neužtikrinanti infrastruktūros irenginių renovacijos poreikio.

Naudojamų žemès ūkio naudmenų plotas Lietuvoje 1970-1989 m. sumažèjo 62,4 tūkst. ha, 19902010 m. - 766,1 tūkst. ha. Pagrindinis rezervas padidinti naudojamų žemès ūkio naudmenų plotą - apleistos žemès. Atmetus sodininkų bendrijų ir smulkiausių ūkių nedeklaruojamą žemę, statistinių 
žemès ūkio naudmenų plotas pagal žemès valstybinę apskaitą sudaro apie 3300 tūkst. ha. Deklaruota žemès ūkio veiklai naudojamų žemès ūkio naudmenų 2004 m. - 2572 tūkst. ha; 2008 m. - 2615 tūkst. ha; 2009 m. -2636 tūkst. ha; 2010 m. -2677 tūkst. ha; 2011 m. -2715 tūkst. ha; 2012 m. - 2763 tūkst. ha; 2013 m. - 2803 tūkst. ha. Taigi, sąlyginai apleistų žemès ūkio naudmenų plotas 2005-2008 m. sumažèjo 64 tūkst. ha, 20092013 m. - 167 tūkst. ha ir šiuo metu sudaro apie 500 tūkst. ha. Siektina, kad tolesnis apleistų žemès ūkio naudmenų ijungimas ị deklaruojamą žemę leistų padidinti (atkurti) naudojamus žemès ūkio naudmenų plotus tose vietovèse, kur yra našesni dirvožemiai ir įrengtos sausinimo sistemos, dar bent 250-300 tūkst. ha plote.

Šalyje susiformavo trys pagrindinès ūkiu grupès: neprekiniai šeimos ūkiai, ūkininkų ir kitų prekinę žemès ùkio produkciją auginančių fizinių asmenų ūkiai ir prekinę žemès ūkio produkciją auginančių juridinių asmenų (žemès ūkio bendrovių bei kitų i̇monių) ūkiai. Dèl vykstančio ūkių restruktūrizavimo proceso mažèja ūkių skaičius ir dideja vidutinis ūkio dydis. 2003-2010 m. smulkiųjų ūkių, turinčių iki 5 ha naudojamų žemès ūkio naudmenų (vidutiniškai po 2,7 ha), skaičius sumažèjo nuo 168,9 tūkst. iki 117,5 tūkst.; ūkių, turinčių 5-20 ha (vidutiniškai po 9,3 ha), sumažèjo nuo 85,4 tūkst. iki 61,4 tūkst., o fizinių ir juridinių asmenų ùkių, turinčių daugiau kaip 20 ha, padidejjo nuo 17,5 tūkst. iki 20,0 tūkst.; vidutinis jų ūkio plotas padidèjo nuo 70 iki 88 ha.

Žemès ūkio naudmenos šalyje panaudojamos skirtingu intensyvumu. Skaičiuojant vienam našumo balui, Vidurio Lietuvos regiono ūkiuose bendrosios augalininkystès produkcijos vertè siekia $42 \mathrm{Lt} / \mathrm{ha}$, o Rytų Lietuvos ir Vakarų Lietuvos regionuose - tik 28-29 Lt/ha. Javų ir kitu prekinių žemès ūkio augalų plotas, skaičiuojant nuo visų naudojamų žemès ūkio naudmenų, atskiruose Vidurio Lietuvos rajonuose siekia 70-88 \%, o kai kuriuose Rytu Lietuvos rajonuose jis tesudaro tik 9-13 \% (Aleknavičius ir kt., 2012). Tai rodo, jog žemès ūkio naudmenų ir pasèlių struktūra ne visuose rajonuose atitinka rekomenduojamą ūkių specializaciją ịvertinant dirvožemių savybes. Šie skirtumai priklauso nuo įvairių priežasčių, pavyzdžiui, stambiųjų ūkių reorganizavimo ypatumų, nevienodo kaimo gyventojų tankumo ir gyvenamųjų vietovių pasiskirstymo, sukurtos socialinès ir žemès ūkio infrastruktūros, gaunamų pajamų, valstybės paramos apimčių.

Pažymètina, kad teritorijų tvarkymo bei teritorijų planavimo dokumentų rengimo teisinès ir metodinès nuostatos sudaro galimybę planuoti naujas statybas ir miško ịveisimą našioje dirbamoje žemeje. Miško žemès pavertimas kitomis naudmenomis galimas tik išimtiniais atvejais, numatant už tai kompensuoti valstybei miško išauginimo ir kitas išlaidas. Žemès ūkio naudmenu su derlinguoju dirvožemiu panaudojimas statiniams nuo $2000 \mathrm{~m}$. galimas nekompensuojant valstybei žemès ūkio gamybos nuostolių. Tai skatina žemès sklypų susmulkinimą, jų nenaudojimą pagal nustatytą paskirti. Aktyviausia urbanistine plètra vyksta arti didžiųjų miestų ir rekreacinèse teritorijose. Nustatyta, jog per metus dèl urbanistinès plètros žemès ūkio naudmenų plotas sumažèja apie 3 tūkst. ha (A. Aleknavičius, P. Aleknavičius, 2010). Tam turi itakos, kad naujos statybos dažniausiai vyksta buvusioje ariamoje žemeje, nes miškų ūkio paskirties ir konservacinès paskirties žemèje statybų planavimas daugeliu atvejų draudžiamas.

Gana svarbi problema yra ir melioracijos įrenginių bei žemès ūkio veiklai naudojamų kelių būklès blogejimas. Pagal Žemès ūkio ministro įsakymais (2005 09 21, Nr. 3D-447; 200812 08, Nr. 3D-650; 201110 19, Nr. 3D-772) tvirtinamas melioracijos programas, būtinas kasmetinis lèšu poreikis sausinimo sistemų rekonstrukcijai - apie $130 \mathrm{mln}$. Lt, tačiau gaunamas finansavimas sudaro tik apie $1 / 3$ poreikio, rūgščios dirvos apskritai nekalkinamos. Žemètvarkos planavimo dokumentų analizè parodè, jog 100 ha teritorijos ploto vidutiniškai tenka $0,7-1,0 \mathrm{~km}$ vietinès reikšmès viešųjų kelių, iš kurių su žvyro danga - 64,7 \%, gruntinių kelių - 29,9\%. Tik 5-25 \% kelių būklè gera, likusių - patenkinama ir bloga. Be šių kelių, dar iki 50 \% viso kelių tinklo sudaro vietinès reikšmès vidaus keliai, naudojami privažiavimams prie gamybinių objektų, mažu gyvenviečių ir sodybų grupių. Juose reikalingų gerinti kelių poreikis yra dar didesnis.

Nors augalininkystès produkcijos rodikliai Lietuvoje nèra blogesni nei buvo iki 1990 m., tačiau gyvulių skaičius per agrarinių reformų laikotarpi šalyje labai sumažèjo: palyginti su 1989 m., ūkiuose 2012 m. karvių skaičius sudare $39 \%$, kiaulių - $30 \%$ buvusio kiekio. Tai ne tik stambiujuc ùkiu likvidavimo, bet ir nepakankamos paramos smulkiųjų (šeimos) ūkių išsaugojimui padarinys. 
Pavyzdžiui, Lietuvos kaimo plètros 2007-2013 m. programoje jaunųjų ūkininkų įsikūrimui skirta $294,9 \mathrm{mln}$. Lt, paramai smulkiesiems (pusiau natūriniams) ūkiams - 98,2 mln. Lt, o šių ūkių savininkų ankstyvam pasitraukimui iš prekinès žemès ūkio gamybos - 467,3 mln. Lt. Dèl šios priežasties bei blogèjančios demografinès situacijos 2003-2010 m. ūkių, laikančių karves, skaičius sumažèjo nuo 193,4 tūkst. iki 85,0 tūkst., ūkiuose laikomų sutartinių galvijų sumažejo 21,9 \%, kiaulių - 21,0\%.
Lyginant Lietuvos žemès naudojimo intensyvumo rodiklius su panašias žemès naudojimo sąlygas turinčių užsienio valstybių rodikliais galima teigti, jog Lietuva turi potencines galimybes atkurti buvusi žemès ūkio gamybos lygị. Moksliniais tyrimais (Aleknavičius ir kt., 2011) nustatyta, kad pagal ploto vienete galimos išauginti žemès ūkio produkcijos vertę Lietuva iš kaimyninių valstybių aplenkia tik Latviją ir šios produkcijos gauna apie 3 kartus mažiau, nei vidutiniškai senosiose ES valstybèse (2 lentelè).

\section{2 lentelè. Lietuvos ir kitų ES šalių žemės ūkio gamybos palyginamieji rodikliai $2007 \mathbf{m}$.}

Table 2. Comparable indicators of agricultural production in Lithuania and other EU countries in 2007

\begin{tabular}{|c|c|c|c|c|c|c|c|c|c|}
\hline $\begin{array}{l}\text { Nr. } \\
\text { No. }\end{array}$ & $\begin{array}{l}\text { Rodikliai } \\
\text { Indicators }\end{array}$ & 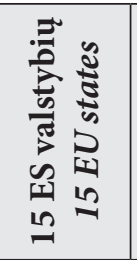 & 坣 & : & 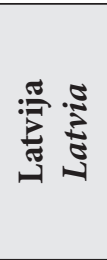 & 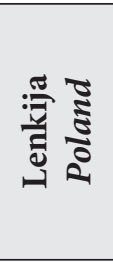 & 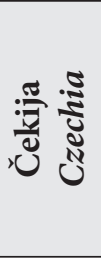 & 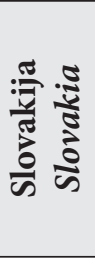 & 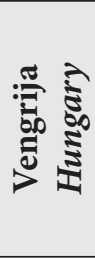 \\
\hline 1. & $\begin{array}{l}\text { Žemès ūkio naudmenos tūkst. ha } \\
\text { Farming lands, thous. ha }\end{array}$ & 137364 & $2695^{\star}$ & 823 & 1839 & 16177 & 4249 & 1930 & 5807 \\
\hline 2. & $\begin{array}{l}\text { Ariamoji žemè tūkst. ha } \\
\text { Arable land, thous. ha }\end{array}$ & 70257 & 1835 & 598 & 1188 & 12502 & 3032 & 1377 & 4592 \\
\hline \multirow[t]{4}{*}{3.} & $\begin{array}{l}1 \text { ha ariamosios žemès išauginta: } \\
\text { Production from } 1 \text { ha arable land: }\end{array}$ & & & & & & & & \\
\hline & - grūdų t / - cereal, $t$ & 2,8 & 1,6 & 1,4 & 1,3 & 2,2 & 2,4 & 2,0 & 2,1 \\
\hline & - bulvių t / - potatoes, $t$ & 0,5 & 0,3 & 0,2 & 0,5 & 0,9 & 0,3 & 0,2 & 0,1 \\
\hline & - cukrinių runkelių $\mathrm{t} /$ - sugar beets, $t$ & 1,3 & 0,4 & - & 0,01 & 1,0 & 1,0 & 0,6 & 0,4 \\
\hline \multirow[t]{2}{*}{4.} & $\begin{array}{l}\text { Pagaminta } 1 \text { ha ž. ù. naudmenų: } \\
\text { Production from } 1 \text { ha farming lands: }\end{array}$ & & & & & & & & \\
\hline & - pieno $\mathrm{t} /-$ milk, $t$ & 0,83 & $0,50^{*}$ & 0,72 & 0,34 & 0,54 & 0,58 & 0,50 & 0,25 \\
\hline \multirow[t]{4}{*}{5.} & $\begin{array}{l}\text { Laikoma } 100 \text { ha ž. ù. naudmenų: } \\
\text { Raising in } 100 \text { ha of farming lands: }\end{array}$ & & & & & & & & \\
\hline & - galvijų / - cattle & 55 & $29^{*}$ & 29 & 21 & 33 & 32 & 26 & 12 \\
\hline & - kiaulių / - pigs & 91 & $34^{*}$ & 46 & 23 & 109 & 63 & 49 & 67 \\
\hline & - avių / - sheeps & 60 & 2 & 9 & 3 & 2 & 4 & 18 & 21 \\
\hline \multirow[t]{4}{*}{6.} & $\begin{array}{l}\text { Žemès ūkio produkcijos vertè: } \\
\text { Value of agricultural production }\end{array}$ & & & & & & & & \\
\hline & - mln. EUR / - mil. EUR & 269608 & 1717 & 558 & 880 & 18388 & 3953 & 1705 & 5779 \\
\hline & $\begin{array}{l}\text { - EUR/ha ž. ù. naudmenų } \\
\text { - EUR/ha of farming lands }\end{array}$ & 1963 & 637 & 678 & 479 & 1137 & 930 & 883 & 995 \\
\hline & $\begin{array}{l}\text { - palyginimas su Lietuvos rodikliais } \\
\text { - comparison with Lithuanian indicators }\end{array}$ & 3,08 & 1 & 1,06 & 0,75 & 1,78 & 1,46 & 1,39 & 1,56 \\
\hline
\end{tabular}

Šaltiniai / Sources: Eurostat; The World Factbook. Central Intelligence Agency. The Work of a Nation

Pastaba / Note: ${ }^{\star} 1989$ m. Lietuvoje, skaičiuojant pagal tuometini žemès ūkio naudmenų plotą (3 514 tūkst. ha), 100 ha žemès ūkio naudmenų buvo laikoma 69 galvijai ir 78 kiaulès, iš viso šalyje prikulta 3272 tūkst. t grūdų, o pieno gamyba sieke 0,92 t/ha / Calculating the Lithuania farming land area in 1989, 69 cattles and 78 pigs were kept in 100 ha, totally in the country there were harvested 3272 thous. $t$ of cereals, milk production was $0.92 \mathrm{t} / \mathrm{ha}$. 
Žemès ūkio paskirties žemès naudojimo intensyvinimas. Siekiant pagerinti žemès naudojimą, buvo analizuojamos priežastys, turinčios įtakos išauginamos žemès ūkio produkcijos apimtims. Gamtinemis-ekonominemis priežastimis laikytinas žemès našumo balas $(B)$. Žemès našumas - tai žemès ūkio naudmenų dirvožemio gebejjimas išauginti augalų derlių. Žemès našumui turi įtakos dirvožemio gamtinès savybès (uoliena, tipas, granuliometrinè sudètis), klimatinès sąlygos, žmogaus atlikti dirvožemio ūkines savybes gerinantys darbai (užmirkusių plotų sausinimas, rūgščiu dirvų kalkinimas, akmenų išrinkimas ir kt.). Pagal VIt Registrų centro duomenis apie Nekilnojamojo turto kadastre $2011 \mathrm{~m}$. sausio $1 \mathrm{~d}$. ịregistruotų 1056 tūkst. žemès ūkio paskirties žemès sklypų našumą, vidutinis našumo balas $B$ atskiruose rajonuose kinta nuo 32,7-33,2 (Trakų r., Druskininku sav.) iki 51,65-52,35 (Kèdainių, Pasvalio r.); vidutiniškai Lietuvoje $-41,85$ balai. Našesnèse žemèse intensyvesnis žemès ūkio naudmenų naudojimas galimas ne tik dèl gaunamo didesnio derliaus esant toms pačioms sąnaudoms, bet ir dèl dirvožemių tinkamumo îvairesniems, prekinei žemès ūkio produkcijai skirtiems, pasèliams auginti. Organizacinèmis priežastimis laikytinos ūkininkavimo sąlygos: apsirūpinimas gamybos priemonèmis ir žeme. Žemès ūkio produkciją auginantys ūkiai vertinami kaip teritorinès gamybinès sistemos, kurių sẻkmingas funkcionavimas priklauso nuo atskirų komponentų - gamybinių statinių, žemės sklypų, juos jungiančių kelių, žemès ūkio technikos, gyvulių, specializuotų tam tikrai veiklai dirbančiųjų apimčių ir išsidèstymo tarpusavio suderinimo. Ükių reorganizavimo laikotarpiu dalis šių komponentų buvo sunaikinti, perskirstyti ar pradèti kurti naujai. Nustatyti vieną bendrą rodikli, išreiškiantị ūkininkavimo sąlygas, sudètinga, todèl priimta prielaida, kad šios sąlygos palankiausios tose vietovèse, kur išliko daugiau buvusių stambių žemès ūkio įmonių pastatų, irrenginių, žemès ūkio technikos ir gyvulių, o ūkio dydis leidžia taikyti intensyviai gamybai rekomenduojamas technologijas. Buvusių žemès ūkio įmonių turtą daugiausiai išsaugojo pagal naujus Lietuvos Respublikos ịstatymus susikūrę žemès ūkio bendrovès ir kitų formų juridinių asmenų ūkiai. Todèl ùkininkavimo sąlygų rodikliu $(U)$ priimtas stambiųjų ūkių išsaugojimo laipsnis, išreikštas juridinių asmenų valdomų žemès ūkio įmonių nau- dojamo ploto santykiu su visu naudojamų žemès ūkio naudmenu plotu (\%). Rodiklio $U$ reikšmès šalies rajonuose - nuo 0 iki 43,6 \%, vidutiniškai Lietuvoje - 13,6 \%.

Siekiant nustatyti, kokią ịtaką žemès naudojimo intensyvumui turi gamtinès sąlygos ir kokią sąlygos, lemiančios žemès ūkio gamybą žemès reformos metu pertvarkytose ūkinèse struktūrose, atlikta vidutinių rodiklių koreliacinè analizè. Gauta daugialypés regresijos lygtis:

$$
I=2,1 B+0,74 U-45,07 \text {; }
$$

$I$ - žemès naudojimo intensyvumo rodiklis;

$B$ - žemès našumo balas;

$\bar{U}$ - stambiụjų ùkių išsaugojimo laipsnio rodiklis.

Šios daugialypès koreliacijos koeficientas $r=0,8618$, determinacijos koeficientas $R^{2}=0,7426$, esant patikimumo lygmeniui $t>2$ (99\%), Fišerio kriterijus - 64,9. Likusius 25,7 \% lemia kiti tyrimuose neišnagrinèti veiksniai. Jais gali būti:

- sparčiai mažejantis gyventojų skaičius dèl migracijos ir mažesnio gimstamumo;

- nepakankama valstybès parama žemès ūkio gamybos plètrai ir ūkininkavimo sąlygų išlyginimui nenašių žemių rajonuose;

- dominuojanti gyvulininkystès specializacija, reikalaujanti auginti daugiau pašarams skirtų pasèlių.

Gauti duomenys leidžia teigti, jog intensyviausiai žemė naudojama rajonuose, pasižyminčiuose našiais dirvožemiais, ir kuriuose yra išlikę daugiau stambių ūkių, išsaugojusių buvusių žemès ūkio imoniu gamybini potencialą.

Lietuvoje, sudarius galimybes didinti žemès ūkio gamybą, o kai kur, atkūrus buvusi jos lygit, turètų padidèti intensyviai naudojamų žemès ūkio naudmenų plotai. Galvijų skaičius turètų didèti rajonuose, kuriuose dèl gamtinių sąlygų ar sejjomainos poreikio planuojamas žalienų (pievų, ganyklų ir daugiamečių žolių) plotas pagal normatyvus bus didesnis, nei jo reikia šiuo metu ùkiuose laikomų galvijų ir kitų ganomų gyvulių aprūpinimui žoliniais pašarais. Lietuvos Respublikos teritorijos bendrajame plane (Lietuvos..., 2002a) nustatyta, kad šalyje yra 17 rajonu (savivaldybių), kuriuose dèl dirvožemio savybių ir kitų sąlygų rekomenduojama prioritetinè ūkių specializacija - kviečiu ir rapsų auginimas, ir 12 
rajonų (savivaldybių), kuriems rekomenduojama prioritetinè pieno-mésos galvijininkystès specializacija bei jiems reikalingų pašarinių augalų auginimas. Prognozuojant žemès ūkio augalų pokyčius pagal optimistini variantą galima priimti, kad dèl sèjomainos ypatumų daugiametès žolès, kiti ekstensyviai naudojami plotai ir pūdymai sudarys nuo potencialiai tinkamų ariamajai žemei plotų pirmosios grupès rajonuose (savivaldybèse) apie $22 \%$, antrosios grupes rajonuose (savivaldybèse) - $45 \%$, likusiuose rajonuose (savivaldybèse) - $35 \%$, o esamas pievų ir ganyklų plotas išliks nepakitęs. Be to, ịsavinus dali apleistų žemès ūkio naudmenų (nusausintoje žemèje ir kituose mechanizuotam dirbimui tinkamuose laukuose) padidès ir bendras visų žemès ūkio naudmenų plotas.

Esant dabartinėms žemès ūkio raidos tendencijoms intensyviai naudojamų žemès ūkio naudmenų plotas taip pat gali didèti dèl palyginti lengvesnių sąlygu augalininkystei plètoti: Visuotinio žemès ūkio surašymo duomenimis, 2003-2010 m. bendras šių pasèlių (javų, linų, rapsų, bulvių, daržovių, cukrinių runkelių ir pašarinių šakniavaisių) plotas vidutiniškai kasmet didejo po 37,8 tūkst. ha arba 3,4 \%. Tačiau galvijų skaičius per tą pati laikotarpi vidutiniškai per metus mažèjo po 22 tūkst., iš jų karvių - po 14 tūkst., todèl nesant radikalių valstybès priemonių padéčiai pagerinti, galvijų skaičiaus ir galvijininkystès produkcijos mažejimą bus sunku stabilizuoti.

Tinkamas žemès klausimų sprendimas turètų ittakos žemès ūkio veikla kaime užsiimančių šeimų išsaugojimui ir naujų ūkių sukūrimui, o tai leistų sustabdyti gyvulių skaičiaus mažejimą, ypač nenašių žemių regionuose, kur pagal mokslines rekomendacijas tikslinga vystyti pienininkystę, galvijininkystę ir avininkystę. Dabartinè valstybès ir ES parama $\mathfrak{i}$ tai neatsižvelgia. Nors Lietuvoje optimalus miškingumas jau pasiektas, be to, miškais savaime apauga apleistos žemès, miškų ịveisimui dirbamose žemèse skiriama daugiau finansinès paramos, nei sausinimo sistemų rekonstrukcijai.

Žemès ūkiui palankios žemès politikos formavimas. Atsižvelgiant $i$ bendruosius reikalavimus žemès, kaip išskirtinès reikšmès gamtos ištekliaus, racionaliam naudojimui Lietuvos Respublikos valstybės politika kaimiškujų teritorijų naudojimo srityje turètų vadovautis šiomis nuostatomis:

1. Žemès ūkio naudmenų, kaip išskirtinès svarbos riboto ploto teritorijų, išsaugojimas ir jų ūki- nių savybių gerinimas, apleistų žemių su našiais dirvožemiais panaudojimas žemès ūkio veiklai. Naudojamų žemès ūkio naudmenų plotas Lietuvoje turètu padidèti bent iki $3 \mathrm{mln}$. ha ir toliau išlikti saugomas, nemažinamas. Derinant žemès ūkio naudmenų ir miškų bei kitų natūralių naudmenų išsidèstymą, būtina siekti ekologinio balanso ir atskirų teritorijų miškingumo padidinimo. Tačiau, ivvertinus mokslines rekomendacijas, mišku plotas Lietuvoje turètu padidèti iki $2,3 \mathrm{mln}$. ha ir toliau išlikti stabilus nesikèsinant $\mathfrak{i}$ žemès ūkio veiklai naudojamus plotus.

2. Intensyvus ūkininkavimas žemès ūkio paskirties žemèje auginant dirvožemio savybes geriausiai atitinkančius augalus tausojamajai žemdirbystei nustatytomis sąlygomis.

3. Kraštovaizdžio ekologinès ịvairovès ir kultūrinio kraštovaizdžio formavimo reikalavimų užtikrinimas, planingai išdèstant kaimo vietoveje statinius, ariamosios žemès ir pievų sklypus, miškus ir laukų apsauginius želdinius, natūralias žemès naudmenas.

4. Ilgalaikių ūkinių struktūrų, turinčių stabilias žemès valdas ir užtikrinančių efektyvų žemès ūkio paskirties bei miškų ūkio paskirties žemès naudojimą, sukūrimas.

5. Perspektyvių kaimo gyvenamujų vietovių, užtikrinančių gyvybingų ūkių funkcionavimą, išsaugojimas bei atkūrimas, taip pat žemès ūkio, miškų ūkio ir kitai veiklai reikalingos infrastruktūros (gerų kelių tinklas, melioracijos įrenginiai, gyventojų aptarnavimo ịstaigos ir kt.) sukūrimas.

6. Skirtingas ūkininkavimo sąlygas turinčių šalies regionų gyventojų pajamų iš žemès ūkio veiklos išlyginimas ekonominemis priemonèmis.

Šios nuostatos gali būti igyvendintos atitinkamai patikslinus įstatymus ir įdiegus kaimo plètros tikslus atitinkančiu teritorijų planavimo dokumentų rengimo sistemą.

Siekiant apsaugoti derlingąji dirvožemị, būtinos Žemès įstatymo (Lietuvos..., 2004b) pataisos, itteisinančios derlingajji dirvožemio sluoksnį žemès savininko nuosavybe tik jeigu žemè buvo ar gali būti naudojama auginti žemès ùkio augalus, miško ir kitus sodinius. Tuomet keičiant žemès naudojimo paskirtị ar panaudojant žemès ūkio naudmenas statiniams, už žemès ūkio naudmenu ploto sumažinimą turi būtų reikalaujama atlyginti nuostolius ne žemès savininkui, o valstybei (visuomenei). Analogiškas principas apsaugant 
miško žemę yra pritaikytas $2011 \mathrm{~m}$. priimtose Miškų i̊statymo pataisose (Lietuvos..., 2001). Pagrindinių siūlomų pakeitimų esmè: už žemès ūkio naudmenas, leistas panaudoti ne žemès ūkio veiklai, turètų būti mokama kompensacija, kurios dydis priklauso nuo dirvožemio atkuriamosios vertès, įdètų lèšų melioracijos darbams, žemès našumo, žemès ūkio veiklai sukurtos infrastruktūros ittakos žemès rinkos kainai. Sumokètos piniginès kompensacijos ittraukiamos i valstybès biudžeto pajamas, jų apskaita tvarkoma specialia žemès ūkio naudmenų gerinimo finansavimo programa ir naudojamos žemès melioravimo darbams (įskaitant projektavimą ir vykdymą) finansuoti. Siekiant išsaugoti nuo iššvaistymo žemès ūkio naudmenas, rekomenduotina teisès aktuose ịtvirtinti nuostatą, jog îveisiant miškus perduoti našių žemès ūkio naudmenų ir nusausintos žemès ūkio paskirties žemès plotus galima tik išimtiniais atvejais, ir jei pagal konkrečios vietovès kaimo plètros žemètvarkos projektą nustatoma, kad šių miškų ịveisimas būtinas norint užtikrinti rekomenduojamą teritorijos miškingumą ir kultūrinio kraštovaizdžio formavimo reikalavimus.

Siekiant sumažinti apleistų žemių plotus ir tuo pačiu padidinti naudojamų žemès ūkio naudmenų plotus, tikslinga teisès aktuose numatyti:

- lengvatines sąlygas perkant apleistos valstybinès žemès sklypus, parduodant juos žemès ūkio veiklos subjektams, jeigu jiems ịsigijus šią žemę bus pagerintas žemès valdų kompaktiškumas;

- teikti valstybès paramą žemès ùkio veiklos subjektams, ịsigyjantiems apleistą privačią žemę (pvz., žemei pirkti paimtų kreditų palūkanų apmokèjimą), jeigu jiems ịsigijus šią žemę bus pagerintas žemès valdų kompaktiškumas;

- lengvatas apmokestinant apleistos žemès sklypus, jeigu jų savininkas vykdo žemès gerinimo priemones ir atkuria buvusią žemès ūkio naudmeną. Taip pat istatyme tikslinga nurodyti, jog privačios žemès savininkams, nepradejusiems gerinti apleistos žemès, galimos naudoti žemès ūkio veiklai, žemès mokestinè vertè padidinama suma, lygia darbų sąmatai atkuriant apleistos žemès buvusias ūkines savybes - atkuriamajai melioracijai;

- numatyti būdus (iš biudžeto lèšų arba ịsteigus siūlomą specialią žemès ūkio naudmenų gerinimo finansavimo programą) kompensuoti dali ūkių lěšų, išleistų apleistų žemių melioravimo darbams.
Igyvendinant valstybès administracines priemones būtina panaudoti teritorijų planavimo dokumentus, kurie bus rengiami vadovaujantis naujos redakcijos Teritorijų planavimo istatymu (Lietuvos..., 2004a). Planavimo organizatoriai ir planu rengejai turètų vadovautis norminiais dokumentais, teisiškai reglamentuojančiais žemès tvarkymo darbus ir žemès naudmenų pavertimą kitomis naudmenomis. Šiuo metu teisès aktai ir metodiniai dokumentai neužtikrina derlingų žemès ùkio naudmenų apsaugos teisinemis bei ekonominèmis priemonèmis, nepakankamai ginami žemès ūkio paskirties žemės naudotojų interesai. Būtinos įstatymų pataisos, kurios numatytų žemès ūkio naudmenų ir miškų naudojimo prioritetus, konkrečius reikalavimus planuojant dirbamos žemès laukus, kelius, užstatytų teritorijų, miškų ir kitų želdinių išdèstymą ir optimizuojant ūkinių struktūrų žemènaudas. Šalies žemès fondo perspektyvinis panaudojimas turi būti reguliuojamas pagal parengtus teritoriju planavimo dokumentus, kuriuose esamo žemès naudojimo pakeitimai sprendžiami atsižvelgiant $\mathfrak{i}$ gyventojų bei ịvairių ūkio sričių interesų balansą. Agrarinėms teritorijoms rengiamuose planuose turi būti pažymèti žemès ùkio veiklai naudotini dirbamos žemès ir pievų sklypai, kaimų ribos, konkretūs plotai, numatomi urbanizuoti, taip pat žemès plotai, numatomi panaudoti miškų ūkio veiklai. Laikantis metodinių reikalavimų formuojant kultūrini kaimiškąji kraštovaizdi galima užtikrinti, kad pertvarkomas kraštovaizdis atitiktų mokslinių rekomendaciju reikalavimus teritorijų naudojimo funkcionalumo, ekologinio stabilumo ir kraštovaizdžio estetiškumo požiūriu. Patikslinus įstatymų nuostatas, užstatymo planai galètų būti rengiami žemès ūkio naudmenų panaudojimą kitai paskirčiai susiejant su planavimo organizatoriaus issipareigojimu kompensuoti valstybei (visuomenei) derlingojo dirvožemio ir žemès ùkio naudmenu sumažinimo nuostolius.

Esant galimybei, paramą žemès ūkio ir kaimo plètrai tikslinga susieti su teritoriju planavimo dokumentų sprendiniais, metodinèmis rekomendacijomis žemès ūkio gamybai ir Žemès informacinès sistemos duomenimis. Valstybès priemonès, skatinančios efektyvų žemès ūkio paskirties žemès naudojimą, turètų būti parengtos taip, kad skatintų ūkius:

- įsigyti arba išsinuomoti apleistas valstybines ir privačias žemes su našiais dirvožemiais bei atlikti 
reikalingą sausinimo sistemų remontą ir rekonstrukciją;

- geriau išnaudoti turimus pievų ir ganyklų su kultūriniais žolynais plotus didinant galvijų ir avių skaičių, išarti bei panaudoti prekinei produkcijai skirtų pasèlių auginimui buvusioje ariamoje žemejje iqrengtas pievas bei ganyklas, jeigu jų plotas didesnis nei būtinas pagal normatyvus aprūpinant pašarais ūkiuose laikomus gyvulius;

- siekti, kad žemés ūkio paskirties žemèje neliktų nenaudojamų žemès ūkio naudmenų, o visos žemès ūkio naudmenos būtų naudojamos tokiu intensyvumu, kuris leidžia gauti didžiausią ūkiams reikalingos augalininkystès produkcijos kieki nepažeidžiant agrotechninių reikalavimų kaitaliojant pasèlius sejomainose, gerinant dirvožemio struktūrą, išsaugant ir didinant humuso kiekį, subalansuojant tręšimą mineralinèmis ir organinèmis trąšomis, saugant pasèlius nuo piktžolių, kenkejuc ir ligų. Tokios tausojamojo ūkininkavimo priemonès gali būti igyvendintos tik remiantis ŽIS duomenimis apie žemès ūkinių savybių pokyčius bei vadovaujantis kompleksiniais žemès ūkio ir kaimo plètros projektais, kuriuose nustatomos atskirų žemés plotų naudojimo perspektyvos.

Žemès naudojimo optimizavimui didelę įtaką gali turèti valdymo institucijų vykdomas teritorijų planavimo reikalavimų igyvendinimas ir žemès naudojimo kontrolè. Šių institucijų veiklą pagerintų ir teisès aktų papildymas konkrečiais normatyvais, reglamentuojančiais našių žemès ūkio naudmenų plotų apsaugą ir jų mažinimo sąlygas, racionalaus dydžio ir formos žemès sklypų projektavimo reikalavimus, privalomą teritorijų planavimo dokumentų derinimą su ịstaiga, atsakinga už valstybès žemès politikos igyvendinimą - Nacionaline žemès tarnyba prie Žemès ūkio ministerijos. Ši tarnyba, pagal kompetenciją išduodama planavimo sąlygas teritorijų planavimo dokumentams rengti ir derinanti planavimo dokumentuc sprendinius, turètų kontroliuoti, ar bus pagerintos žemès naudojimo sąlygos ir privažiavimo kelių tinklas, išsaugoti ariamosios žemès plotai ir natūralūs kraštovaizdžiai, suformuotos racionalios žemès sklypų ribos.

\section{IŠVADOS}

1. Žemès ūkio paskirties žemès naudojimo intensyvumą galima išreikšti ploto vienetui tenkan- čiomis žemès ūkio produkcijos gamybos apimtimis arba prekinei produkcijai naudotinu pasèliu procentu bendrame žemès ūkio naudmenų plote. Pagal šiuos rodiklius Lietuvoje intensyviai naudojama tik $54 \%$ visų naudojamų žemès ūkio naudmenų.

2. Pagrindinès priežastys, turinčios ịtakos žemès naudojimo intensyvumui, ir kurių iš esmès pakeisti negalima, yra žemès ūkio naudmenų dirvožemio našumas (žemès našumo balas) ir stambiųų ūkių gamybos komponentų (statinių, žemès ükio technikos, gyvulių skaičiaus, naudojamos žemès ploto) išsaugojimo laipsnis.

3. Intensyviai naudojamų žemès ūkio naudmenų plotas Lietuvoje dèl ūkių stiprejimo ir dirvonuojančios žemès įtraukimo i̇ žemès ūkio veiklą palaipsniui didejja, tačiau 2003-2010 m. galviju skaičius šalyje kasmet mažèjo po 22 tūkst., iš jų karvių - po 14 tūkst.

4. Lietuva turi potencines galimybes atkurti buvusị žemès ūkio gamybos lygị ir padidinti intensyviai naudojamų žemès ūkio naudmenų plotus. Pagrindinemis agrarinių teritorijų naudojimo valstybinio reguliavimo kryptimis laikytina:

4.1. Subalansuoto žemès išteklių paskirstymo ivvairiai naudojimo paskirčiai planavimas ir administravimas užtikrinant našių žemès ūkio naudmenų išsaugojimą.

4.2. Racionalaus dydžio, stabilių ir kompaktiškų žemès valdų sudarymas prekinę žemès ūkio produkciją auginantiems ūkiams.

4.3. Kultūrinio kaimiškojo kraštovaizdžio suformavimas, kompleksiškai sprendžiant gyvenamujjų vietovių statinių, infrastruktūros elementų, dirbamos žemès laukų, miškų ir natūralių žemès naudmenų išdèstymą.

4.4. Žemès ūkio gamybos apimčiu padidinimas ịtraukiant ị intensyvią žemès ūkio veiklą potencialiai derlingas apleistas žemes ir neefektyviai naudojamas žemès ūkio naudmenas.

4.5. Žemès ūkio naudmenų vertingưjų savybių gerinimas panaudojant dirvožemių tyrimo ir kitus žemès informacinès sistemos duomenis.

5. Siekiant padidinti agrarinių teritorijų naudojimo efektyvumą Lietuvoje, būtina:

5.1. Tobulinti norminius teisès aktus, reglamentuojančius teritorijų planavimo dokumentų rengimą ir igyvendinimą bei žemès ūkio naudmenų, kaip išskirtinès reikšmès gamtos ištekliaus, apsaugą. 
5.2. Sustiprinti žemę administruojančiu institucijų funkcijas, kad jų veikloje daugiau dèmesio būtų skiriama planuojant ir tvarkant kaimiškąsias teritorijas, likviduojant apleistas žemes, stiprinant žemès naudojimo kontrolę.

Gauta 20131212

Priimta 20140313

\section{LITERATŪRA}

1. Aleknavičius A., Aleknavičius P. 2010. Žemès ūkio naudmenų ploto pokyčiu perspektyvos Lietuvoje. Vagos: mokslo darbai. Nr. 86(39). P. 28-36.

2. Aleknavičius P., Aleknavičius A., Juknelienè D. 2012. Lietuvos žemès ūkio paskirties žemès naudojimo perspektyvos. Kaimo raidos kryptys žiniu visuomenèje. Nr. 2(4). P. 15-26.

3. Aleknavičius P., Stravinskienè V. 2011. Žemès savybių įtaka žemès ūkio plètrai Lietuvoje. Kaimo raidos kryptys žiniu visuomeneje. Nr. 2. P. 188198.

4. Darbotvarke 21: Subalansuotos pletros veiksmu programa (galutinis sutarčiu tekstas, Vyriausybių svarstytas Jungtinių Tautų aplinkos ir plètros konferencijoje Rio de Žaneire, Brazilijoje, 1992 m. birželio 3-4 d.). 2001. Vilnius: Lietuvos Respublikos aplinkos ministerija.

5. European Charter for Rural Areas. 1996 [žiūrèta 2013-07-09]. Prieiga per internetą: http://assembly.coe.int/Documents/WorkingDocs/doc96/ EDOC7507.htm

6. Jasaitis J. 2008. Neurbanizuotų teritorijų plètros administravimas poindustrinèje visuomenèje. Ekonomika ir vadyba: aktualijos ir perspektyvos. Nr. 1(10). P. 47-63.

7. Lietuvos kaimo pletros 2007-2013 metu programa. 2007 [žiūrèta 2013-02-10]. Prieiga per internetą: http://www.zum.lt/documents/kaimo_pletros_depart/11-0920\%20KPP_LTn.pdf (2013-02-10)

8. Lietuvos Respublikos Konstitucinio Teismo $2006 \mathrm{~m}$. kovo 30 d. nutarimas. Valstybès žinios. 2006b. Nr. 37-1319.

9. Lietuvos Respublikos miškų ịstatymas. $2001 \mathrm{~m}$. balandžio 10 d. Nr. IX-240. Valstybès žinios. 2001. Nr. 35-1161.

10. Lietuvos Respublikos Seimo 2002 m. spalio 29 d. nutarimas Nr. IX-1154 „Dèl Lietuvos Respublikos teritorijos bendrojo plano“. Valstybès žinios. 2002. Nr. $110-4852$.

11. Lietuvos Respublikos Seimo $2002 \mathrm{~m}$. lapkričio 12 d. nutarimas Nr. IX-1187 „Dèl valstybès ilgalaikès raidos strategijos“. Valstybès žinios. 2002. Nr. 113-5029.

12. Lietuvos Respublikos teritorijų planavimo įstatymas. 2004 m. sausio 15 d. Nr. IX-1962. Valstybès žinios. 2004a. Nr. 21-617.

13. Lietuvos Respublikos žemès îstatymas. Valstybès žinios. 2004b. Nr. 28-868.

14. Lietuvos žemès našumas: monografija. Sud. J. Mažvila. 2011. Akademija, Kèdainių r.: Lietuvos žemdirbystes institutas. $280 \mathrm{p}$.

15. Ribokas G. 2010. Šiaurès Rytų Lietuvos kaimo raidos perspektyvos. Ekonomika ir vadyba: aktualijos ir perspektyvos. Nr. 3(19). P. 63-74.

16. Volkov S. A. 2005. Zemlyeustroystvo za rubyezhom. Zemlyeustroystvo. Moskva: „Kolos S“. T. $7.408 \mathrm{~s}$.

Pranas Aleknavičius, Audrius Aleknavičius, Daiva Juknelienè

\section{PROBLEMS AND SOLUTIONS OF THE USE OF AGRARIAN AREAS IN LITHUANIA}

Summary

This paper presents the state overview of the agricultural land of the Republic of Lithuania as well as suggestions for agrarian areas management control. The causes leading to the level of land use intensity were analyzed in this paper. Problematic regions, where land use indicators are worse due to the rapidly shrinking population as well as due to the lack of state support for the farm economy strengthening, were identified. Proposals for agriculture and rural development, which may ensure a more efficient agricultural land use, were presented. Proposals are justified by strategic documents and legal provisions for the conservation of agricultural land as an exceptional value of natural resources. The rational land use issues in Lithuania can be properly solved by improved legislation, by the preparation of spatial planning documents based on scientific recommendations as well as by the return of derelict lands for economic activities. This would stabilize the agricultural land area decrease.

Key words: agricultural land, land use intensity, derelict land, land productivity 